\title{
EVALUASI PROGRAM AKPMM (ALIH KREDIT PENGAKUAN MASA MENGAJAR) DALAM PENINGKATAN KUALITAS PENDIDIKAN JARAK JAUH DI UNIVERSITAS TERBUKA
}

\author{
Dwi Kristanti ${ }^{1}$, Lina Asnamawati ${ }^{2}$ \\ ${ }^{I}$ Program Studi Administrasi Negara Universitas Terbuka UPBJJ Padang \\ ${ }^{2}$ Program Studi Agribisnis Universitas Terbuka UPBJJ Bengkulu \\ dwik@ecampus.ut.ac.id
}

\begin{abstract}
This study aimed to evaluate the program AKPMM (Alih Kredit Pengakuan Masa Mengajar, Credit Transfer Recognition Teaching Period) in improving the quality of long distance education in UPBJJ UT (ADivision of Long Distance Learning Program in the Open University). AKPMM program was evaluated from the dimensions of implementation, effectiveness, and program performance. The location of this research is in the UPBJJ UT Padang and Bengkulu. The sample in this study amounted to 210 students. Simple linear regression was used to test the relationship between the variables in this study. The results of this study indicate that the AKPPM program can be implemented better in UPBJJ UT Padang compared UPBJJ UT Bengkulu. In terms of ratios, the number of students who take the program AKPMM in the UPBJJ-UT Bengkulu larger than UPBJJ UT Padang. In terms of program evaluation, it was found that the program AKPMM more positively impact on the students in UPBJJ-UT Padang compared with the students in the UPBJJ-UT Bengkulu. Thisstudy also found that a significant difference among the implementation, evaluation, and effectiveness variables of AKPMM program in the Open University.
\end{abstract}

Key words: Evaluation, implementation, effectiveness, AKPMM program, Open University

\section{PENDAHULUAN}

Penelitian ini bertujuan ingin mengevaluasi pelaksanaan Program Alih Kredit Pengakuan Masa Mengajar (AKPMM) yang dilaksanakan oleh Universitas Terbuka Penelitian ini penting untuk dilakukan karena keberhasilan dan kegagalan suatu program dapat diketahui jika kita melakukan evaluasi terhadap program tersebut. Evaluasi ternyata telah banyak memberikan manfaat dan kontribusinya didalam memberikan informasi maupun data, khususnya mengenai pelaksanan suatu program tertentu yang pada gilirannya akan menghasilkan rekomendasi dan digunakan oleh pelaksana program tersebut untuk menentukan keputusan, apakah program tersebut dihentikan, dilanjutkan, atau ditingkatkan lebih baik. Evaluasi dapat disajikan dalam konteks perencanaan, pelaksanaan dan penyelesaian suatu proyek, fungsi tersebut menuntut evaluasi sebagai bagian dari proses manajemen proyek (Casley dan Kumar, 1991).

Undang-undang Republik Indonesia Nomor 14 Tahun 2005 tentang Guru dan Dosen mengamanatkan bahwa guru wajib memiliki kualifikasi akademik, kompetensi, sertifikat pendidik, sehat jasmani dan rohani, serta memiliki kemampuan untuk mewujudkan tujuan pendidikan nasional (pasal 8). Kualifikasi akademik sebagaimana dimaksud dalam pasal 8 diperoleh melalui pendidikan tinggi program sarjana atau program diploma empat (pasal 9), sedangkan kompetensi guru sebagaimana dimaksud dalam pasal 8 meliputi kompetensi pedagogik, kompetensi kepribadian, kompetensi 
sosial, dan kompetensi profesional yang diperoleh melalui pendidikan profesi (pasal 10). Selanjutnya ditegaskan bahwa: "guru yang belum memiliki kualifikasi akademik dan sertifikat pendidik wajib memenuhi kualifikasi akademik dan sertifikat pendidik paling lama sepuluh tahun sejak berlakunya undang-undang ini” (pasal 82 ayat 2). Konsekuensi logis dari pemberlakuan undang-undang tersebut, pemerintah dan Penyelenggara Pengadaan Tenaga Kependidikan (PPTK) atau Lembaga Pendidikan Tenaga Kependidikan (LPTK) diharapkan dapat memfasilitasi pelaksanaan program percepatan peningkatan kualifikasi akademik guru dengan akses yang lebih luas, berkualitas dan tidak mengganggu tugas serta tanggung jawabnya di sekolah.

Guna mewujidkan cita-cita tersebut, pemerintah meluncurkan sebuah Program Pengakuan Pengalaman Kerja dan Hasil Belajar (PPKHB)yang bangun berdasarkan beberapa aturan antara lain:

1. Undang-undang No.14/2005: Guru dan Dosen

2. Undang-undang No.20/2003: Sistem Pendidikan Nasional

3. Peraturan Pemerintah No.19/2005: Standar Nasional Pendidikan

4. Peraturan Pemerintah No.74/2008: Guru

5. Peraturan Menteri Pendidikan Nasional No.16/2007: Standar Kualifikasi dan Kompetensi Guru

6. Peraturan Menteri Pendidikan Nasional No.58/2008: Penyelenggaraan Program Sarjana (S1) Kependidikan Bagi Guru Dalam Jabatan

7. Peraturan Menteri Pendidikan dan Kebudayaan No.5/2012: Sertifikasi Guru Dalam Jabatan

8. Peraturan Menteri Pendidikan dan Kebudayaan No. 73/2013: Penerapan KKNI PT

Adapun pengertian dari program PPKHB adalah meliputi berbagai komponen sebagai berikut:

1. Suatu sistem penghargaan terhadap wawasan, pengetahuan, keterampilan, nilai, dan sikap yang mencerminkan pengalaman kerja dan hasil belajar yang dimiliki guru peserta program Sarjana (S-1) Kependidikan bagi Guru Dalam Jabatan sebagai pengurang beban studi yang wajib ditempuh.

2. Hasil Belajar berkaitan dengan kualifikasi akademik yang telah diperoleh, pelatihanpelatihan yang pernah diikuti, dan prestasi akademik yang dicapai.

3. Pengalaman Kerja berkaitan dengan masa bakti, kemampuan dalam menyusun rencana pelaksanaan pembelajaran, dan prestasi tertentu yang diperoleh dalam bentuk penghargaan.

UU Guru dan Dosen juga mempersyaratkan para guru untuk memiliki kualifikasi Sarjana, memacu berbagai pihak terkait untuk dapat memenuhi Undang-undang tersebut. Permendiknas No.58 Tahun 2008, tentang Penyelenggaraan Program Sarjana Kependidikan bagi Guru Dalam Jabatan, Pasal 5 (7) menyatakan perguruan tinggi dapat memberikan pengakuan terhadap pengalaman kerja dan hasil belajar yang pernah diperoleh sebelumnya, baik pada jalur pendidikan formal maupun pendidikan non formal sebagai pengurang beban studi yang harus ditempuh. Selain itu, dalam Permendikbud No. 73 Tahun 2013 tentang Penerapan KKNI dalam Perguruan Tinggi (PT), yang ditegaskan dalam Ramburambu Pengakuan Pengalaman Kerja dan Hasil Belajar (PPKHB) Kemdikbud, menyebutkan bahwa:

1. PT mengakui capaian pembelajaran yang dilakukan oleh perguruan tinggi dan/atau lembaga pendidikan dan pelatihan yang diselenggarakan oleh kementerian dan/atau lembaga di luar pembinaan Kemendikbud dan Kemenag sebagai dasar pemberian gelar yang setara;

2. Mengakui capaian pembelajaran yang diperoleh individu melalui pendidikan nonformal, informal, dan/atau pengalaman kerja sebagai dasar untuk melanjutkan pendidikan formal dalam rangka pembelajaran sepanjang hayat.

Mengacu kepada Permendiknas No.16 Tahun 2007 tentang Standar Kualifikasi 
Akademik dan K;ompetensi Guru, Peraturan Pemerintah (PP) Nomor 74 tahun 2008 tentang Guru yang menyatakan bahwa pengembangan dan peningkatan kompetensi bagi guru dilakukan dalam rangka memenuhi kualifikasi dan menjaga agar kompetensi keprofesiannya tetap sesuai dengan perkembangan ilmu pengetahuan, teknologi, seni dan budaya dan/atau olah raga, maka Universitas Terbuka membuka Program S1 PGSD PPKHB.Berdasarkan SK Rektor UT Nomor 3258/UN31/KEP/2015 tanggal 4 Mei 2015 tentang PPKHB dan SK Rektor no 8481/UN31/KEP/2015 tanggal 9 November 2015 tentang AKPMMFKIP Universitas Terbuka (UT) membuka layanan program pendidikan melalui Pengakuan Pengalaman Kerja dan Hasil Belajar, yang selanjutnya disingkat S1 PGSD AKPMM dengan kode Program 118 dan S1 PG PAUD AKPMM dengan kode program 122.

Berdasarkan uraian permasalahan di latar belakang, maka permasalahan dalam penelitian ini dapat dirumuskan sebagai berikut:

1. Bagaimana implementasi program AKPMM di Universitas Terbuka?

2. Bagaimana efektivitas program AKPMM di Universitas Terbuka?

\section{METODE}

Penelitian ini adalah merupakan penelitian pendekatan kuantitatif dengan jenis penelitian deskriptif. Melalui pendekatan ini diperoleh datadata yang jelas yang memungkinkan kita untuk melihat dan menjelaskan variabel yang mempengaruhi evaluasi implementasi program AKPMM melalui penganalisaan data-data dan angka-angka, serta sebagai uraian dan penjelasan mengenai aspek yang diteliti dari individu yang menggunakan dan melaksanakan program AKPMM di UT. Peneliti berusaha dan berupaya menelaah sebanyak mungkin data yang diteliti.

Dengan pendekatan ini diperoleh data-data empirik yang mungkinkan kita untuk melihat dan menjelaskan variabel yang mempengaruhi kualitas pelayanan melalui penganalisaan datadata dan angka-angka (Tan, 1994: 231). Sedangkan tipe penelitian yang digunakan adalah bersifat deskriptif atau penelitian penggambaran yaitu suatu metode penelitian yang berusaha memberikan penggambaran atas proposisi penelitian yang pada akhirnya memberikan jawaban atas pertanyaan penelitian dan dapat dilakukan pengujian terhadap hubungan antara variabel-variabel penelitian.

Lokasi penelitian bertempat di UPBJJ-UT Padang dan Bengkulu. Teknik pengambilan sampel yang digunakan dalam penelitian ini adalah Simple Random Sampling, yaitu cara pengambilan sampel dan anggota populasi dengan menggunakan acak tanpa memperhatikan strata (tingkatan) apabila populasi diasumsikan homogen (Mengandung satu ciri) sehingga secara acak dengan melakukan undian terhadap populasi (Idrus 2002). Sampel yang diperlukan dalam penelitian ini yaitu $20 \%$ dari jumlah mahasiswa baru program AKPMM di UPBJJ-UT Padang dan Bengkulu. Sampel dalam populasi penelitian ini yaitu seluruh mahasiswa baru AKPMM yang teregistrasi di UPBJJ-UT bengkulu dan UPBJJ-UT Padang. Menurut Sevilla et al. (2006) jika jumlah populasi sangat kecil $(<500)$, maka untuk sampelnya diperlukan minimum $20 \%$. Jumlah sampel yang diambil adalah $20 \%$ dari jumlah populasi. Dengan demikian pada penelitian ini dapat ditentukan sampel penelitian sebagai berikut: (1) populasi S1. PGSD AKPMM di UPBJJ UT Bengkulu sebanyak 375, Jumlah sampel sebanyak 75 mahasiswa; (2) populasi S1. PGSD dan S1. PGPAUD AKPMM UPBJJ-UT Padang sebanyak 675, sampel sebanyak 135

Evaluasi dalam penelitian ini dilakukan dengan memberi penilaian terhadap program AKPMM dan memperbaiki komponenkomponen program tersebut yang ditinjau dari komponen context, input, process, dan product. Evaluasi ini merupakan evaluasi sumatif, yaitu evaluasi yang dilakukan setelah program dilaksanakan dengan menggunakan analisis program model CIPP (context, input, process,, and product) yang dikonfirmasi dengan hal-hal yang diamati (komponen) pada program AKPMM kseluruhan komponen, diidentifikasikan dengan beberapa pertanyaan 
dalam kuisioner berdasar penjabarannya. Setiap komponen dijabarkan menjadi indikator. Penjabaran komponen CIPP analisis program AKPMM.

Jawaban setiap pertanyaan terdiri dari opsi-opsi yang berskala ordinal 1 sampai dengan 3, yang merepresentasikan nilai dengan simbol kuantitatif, dan merupakan gradasi dari sangat tidak setuju sampai dengan sangat setuju. Setelah itu keseluruhan data diolah dengan menggunakan tabulasi distribusi frekuensi dan nilai tengah. Selain itu untuk mengetahui distribusi frekuensi dan persentasi dari masing-masing variabel digunakan juga analisis dengan perangkat lunak SPSS 20.0.

\section{HASIL DAN PEMBAHASAN}

\section{Implementasi Program AKPMM Universitas Terbuka}

Dalam penelitian ini implementasi Program AKPMM Universitas Terbuka dilihat dengan menggunakan empat indikator, yaitu struktur birokrasi, sumber daya, komunikasi dan disposisi. Berikut ini akan dianalisis secara deskriptif hasil atau temuan penelitian dengan mengacu kepada empat variabel tersebut. Penelitian ini menemukan bahwa implementasi Program AKPMM di Universitas Tebuka, dilihat dari indikator struktur birokrasi, sumber daya, komunikasi, dan disposisi sudah terlaksana dengan baik. Secara agregat, baik penelitian di UPBJJ UT Padang maupun di UPBJJ UT Bengkulu, penelitian ini menunjukkan mayoritas responden menyatakan setuju dengan semua indikator yang diteliti. Bahkan, 100 persen responden di UPBJJ UT Padang menyatakan setuju dengan variabel sumber daya, komunikasi, dan disposisi. Sedangkan, di UPBJJ UT Bengkulu 87 persen responden setuju dengan indikator struktur birokrasi, 81 persen responden setuju dengan indikator sumber daya, 71 persen responden setuju dengan indikator komunikasi, dan 84 responden setuju dengan indikator disposisi.

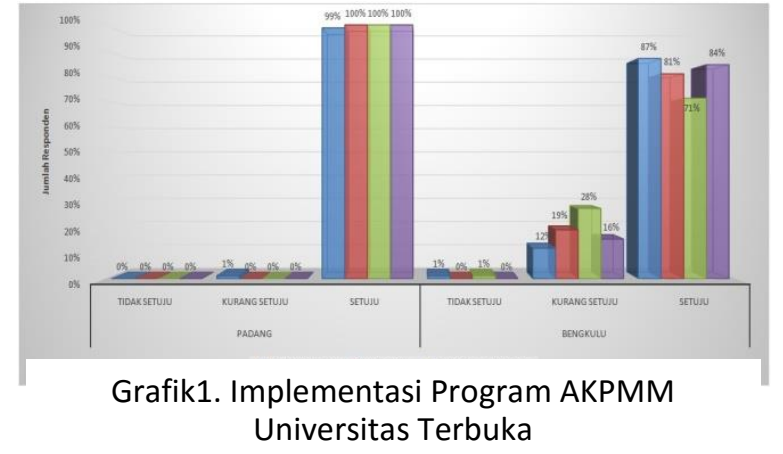

\section{Efektivitas Program AKPMM Universitas Terbuka}

Efektivitas Program AKPMM Universitas Terbuka dalam penelitian ini dilihat dari dua indikator, yaitu kuantitas dan kualitas. Kuantitas mengacu kepada ketersediaan jumlah sumber daya, fasilitas dan infrastruktur yang dibutuhkan dalam mengimplementasikan Program AKPMM di Universitas Terbuka. Sedangkan kualitas berarti mutu dari sumber daya yang sudah dialokasikan untuk mengimplementasikan Program AKPMM. Berikut ini akan dipaparkan hasil penelitian mengenai efektivitas program AKPMM dilihat dari dua indikator tersebut. Dari penelitian ini diketahui bahwa implementasi Program AKPMM sudah efektif. Data penelitian ini menunjukkan mayoritas responden mengungkapkan bahwa kuantitas dan kualitas sumber daya dalam implementasi Program AKPMM berada pada kategori sangat memuaskan. Grafik di bawah ini menunjukkan, 82 persen responden di UPBJJ UT Padang dan 28 persen responden di UPBJJ UT Bengkulu menyatakan bahwa mereka sangat puas dengan kuantitas sumber daya yang dimiliki oleh Universitas Terbuka dalam mengimplementasikan Program AKPMM. Sedangkan, sebanyak 67 persen responden di UPBJJ UT Bengkulu dan 18 persen responden di UPBJJ UT Padang menyatakan puas dengan kuantitas sumber daya Universitas Tebuka. Selebihnya, hanya 5 persen responden di UPBJJ UT Bengkulu yang menyatakan kurang puas. 


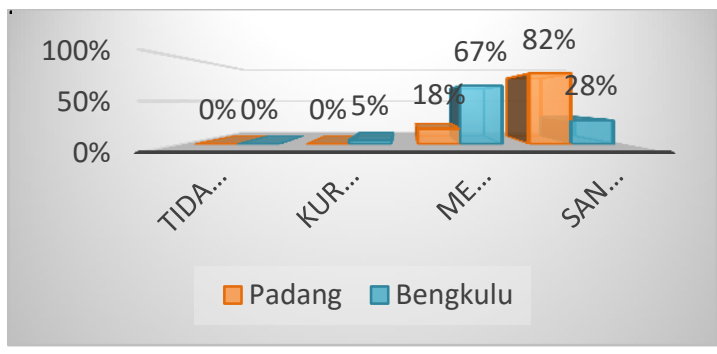

Grafik 2. Persentase Kuantitas Sumber Daya dalam Program AKPMM di UPBJJ UT Padang dan Bengkulu

Dilihat dari indikator kualitas, dapat disimpulkan juga bahwa implementasi Program AKPMM sudah berjalan dengan efektif.Hal ini didasarkan atas penilaian dari responden penelitian ini mengenai indikator kualitas. Grafik 3. mengilustrasikan bahwa 100 persen responden di UPBJJ UT Padang dan 92 persen responden menyatakan setuju dengan pernyataan bahwa kualitas sumber daya yang dialokasikan Universitas Terbuka dalam mengimplementasikan Program AKPMM sudah baik. Sisanya, hanya 8 persen responden yang mengungkapkan kurang setuju dengan pernyataan tersebut.

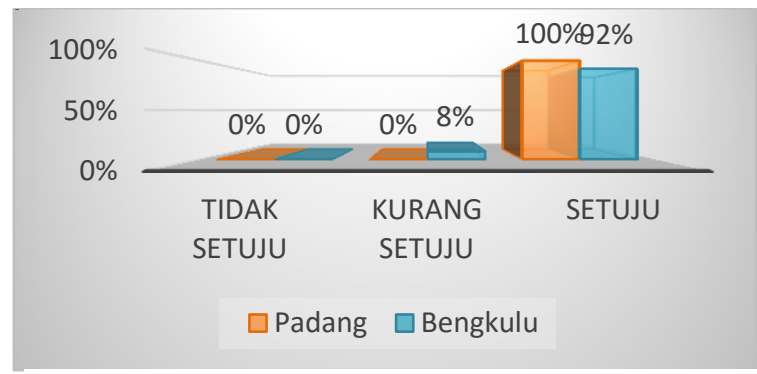

Grafik 3. Persentase Kualitas Sumber Daya dalam Program AKPMM di UPBJJ UT Padang dan Bengkulu

\section{Regresi Linier Sederhana antara variabel bebas $\mathrm{X}$ (Implementasi) dengan Variabel Terikat Y1 (Evaluasi)}

Koefisien determinasi pada regresi linear sering diartikan sebagai seberapa besar kemampuan semua variabel bebas dalam menjelaskan varians dari variabel terikatnya. Berdasarkan hasil pada Tabel 5.1. diperoleh nilai koefisien determinasinya 38,2 \%. Hal ini memberikan interpretasi kemampuan variabel bebas (Unsur-unsur pada Implementasi) dalam menjelaskan varians dari variabel terikatnya (unsur-unsur evaluasi) adalah sebesar 38,2\%. Berarti terdapat $61,8 \%$ varians variabel terikat yang dijelaskan oleh faktor lain yang belum masuk dalam penelitian ini.

Tabel 1. Output Nilai Koefisien Determinasi Variabel X1 dan Y1

\begin{tabular}{|c|c|c|c|c|c|c|c|c|c|}
\hline \multirow[b]{2}{*}{ Model } & \multirow[b]{2}{*}{$\mathrm{R}$} & \multirow[b]{2}{*}{ R Square } & \multirow[b]{2}{*}{$\begin{array}{ll}\text { Adjusted } & \text { R } \\
\text { Square } & \end{array}$} & \multirow{2}{*}{$\begin{array}{l}\text { Std. Error of } \\
\text { the Estimate }\end{array}$} & \multicolumn{5}{|c|}{ Change Statistics } \\
\hline & & & & & $\begin{array}{l}\mathrm{R} \text { Square } \\
\text { Change }\end{array}$ & F Change & df1 & df2 & $\begin{array}{ll}\text { Sig. } & F \\
\text { Change } & \end{array}$ \\
\hline 1 & $.618^{a}$ & .382 & .377 & 12.24968 & .382 & 79.148 & 1 & 128 & .000 \\
\hline a. & $\begin{array}{l}\text { Predicts } \\
\text { X1TOT }\end{array}$ & & (Constant) & & & & & & \\
\hline b. & Depend & t Variable & : Y1TOTAL & & & & & & \\
\hline
\end{tabular}

Tabel 2., merupakan output yang digunakan untuk pengujian model secara simultan atau bersama-sama. Uji yang dilakukan disebut simultan test (F-test) yang bertujuan untuk melihat apakah secara bersama-sama variabel bebas berpengaruh terhadap variabel terikat atau tidak. Prosedur pengujiannya adalah $H_{0}$ : tidak ada variebel bebas yang berpengaruh terhadap variabel terikat. Dengan tingkat signifikansi $\alpha=0,05$, diperoleh hasil pengujian bahwa Sig F (0.0000) < $\alpha$, maka $H_{0}$ ditolak. Dapat disimpulkan dengan tingkat kepercayaan 95\% variabel bebas berpengaruh secara signifikan terhadap variabel terikat.

Tabel 2. Analisis Variansi (ANOVA) X1 dan Y1 


\begin{tabular}{|c|c|c|c|c|c|c|}
\hline & Model & $\begin{array}{l}\text { Sum of } \\
\text { Squares }\end{array}$ & $\mathrm{df}$ & Mean Square & $\mathrm{F}$ & Sig. \\
\hline \multirow[t]{3}{*}{1} & Regression & 11876.503 & 1 & 11876.503 & 79.148 & $.000^{\mathrm{a}}$ \\
\hline & Residual & 19207.005 & 128 & 150.055 & & \\
\hline & Total & 31083.508 & 129 & & & \\
\hline & $\begin{array}{l}\text { Predictors } \\
\text { X1TOTA } \\
\text { Dependen } \\
\text { Y1TOTA }\end{array}$ & : & stant) & & & \\
\hline
\end{tabular}

Tabel 3., selanjutnya merupakan tabel pengujian signikansi dari masing-masing variabel bebas terhadap variabel terikat. Dengan tingkat signifikansi $\alpha=0,05$, diperoleh hasil pengujian bahwa Sig $t$ untuk intersep dan masing-masing variabel berturut-turut 0,002 dan 0,000 . Kedua nilai signifikansi tersebut masih lebih kecil dari nilai $\alpha$, maka $H_{0}$ ditolak. Dapat disimpulkan dengan tingkat kepercayaan 95\%, nilai intersep, dan koefisien dari masing-masing variabel bebas berpengaruh secara signifikan terhadap variabel terikat.

Tabel 3. Nilai Koefisien dari Parameter Regresi X1 terhadap Y1

\begin{tabular}{|c|c|c|c|c|c|c|}
\hline \multirow{2}{*}{\multicolumn{2}{|c|}{ Model }} & \multicolumn{2}{|c|}{$\begin{array}{l}\text { Unstandardized } \\
\text { Coefficients }\end{array}$} & \multirow{2}{*}{\begin{tabular}{|l} 
Standardized \\
Coefficients
\end{tabular}} & \multirow[b]{2}{*}{$\mathrm{t}$} & \multirow[b]{2}{*}{ Sig. } \\
\hline & & B & Std. Error & & & \\
\hline \multirow[t]{2}{*}{1} & (Constant) & 31.781 & 10.213 & & 3.112 & .002 \\
\hline & X1TOTAL & 2.429 & .273 & .618 & 8.897 & .000 \\
\hline & a. Depende & Jariable: Y1TC & OTAL & & & \\
\hline
\end{tabular}

Uji normalitas adalah untuk melihat apakah nilai residual terdistribusi normal atau tidak. Model regresi yang baik adalah model yang memiliki nilai residual yang berdistribusi normal. Jadi uji normalitasnya bukan dilakukan pada masing-masing variabel tetapi pada nilai residualnya. Salah satu cara untuk melihat normalitas dari residualnya adalah dengan melihat grafik histogram yang membandingkan antara data observasi dengan distribusi yang mendekati normal. Pada prinsipnya normalitas dapat dideteksi dengan melihat penyebaran data pada sumbu diagonal dari grafik atau dengan melihat histogramnya dari residualnya.

Jika data menyebar disekitar garis diagonal dan mengikuti arah garis diagonal atau grafik histogramnya menunjukan pola distribusi normal, maka model regresi memenuhi asumsi normalitas.Dengan melihat tampilan grafik histogram maupun grafik normal plot pada gambar 1 dan 2, dapat disimpulkan bahwa grafik histogram memberikan pola distribusi normal. Sedangkan pada grafik normal plot terlihat titiktitik menyebar disekitar garis diagonal. Berdasarkan kedua gambar tersebut di simpulkan data residual berdistribusi normal. Namun demikian untuk lebih memastikan hasil pengujian kenormalan residual, kita gunakan pengujian kolmogorov smirnov. Dalam prosedur pengujian kenormalan kolmogorov smirnov, di hipotesiskan bahwa $H_{0}$ : data mengikuti distribusi normal, dengan kriteria pengujian Tolak $H_{0}$ bila nilai signifikansi $<\alpha$. Berdasarkan hasil tabel diatas, nilai signifikansi $(0.000)<$ dari $\alpha=0,05$ hal ini Ho diterima yang artinya data residual tidak mengikuti distribusi normal. 
Tabel 4. Uji Kolmogorov-Smirnov Untuk Kenormalan Residual Regresi X1 dan Y1

\begin{tabular}{|c|c|c|}
\hline & & $\begin{array}{l}\text { Unstandardized } \\
\text { Residual }\end{array}$ \\
\hline \multicolumn{2}{|l|}{$\mathrm{N}$} & 130 \\
\hline \multirow{2}{*}{$\begin{array}{l}\text { Normal } \\
\text { Parameters }\end{array}$} & Mean & .0000000 \\
\hline & $\begin{array}{l}\text { Std. } \\
\text { Deviation }\end{array}$ & 12.20211080 \\
\hline \multirow{3}{*}{$\begin{array}{l}\text { Most Extreme } \\
\text { Differences }\end{array}$} & Absolute & .270 \\
\hline & Positive & .230 \\
\hline & Negative & -.270 \\
\hline \multicolumn{2}{|c|}{ Kolmogorov-Smirnov Z } & 3.083 \\
\hline \multicolumn{2}{|c|}{ Asymp. Sig. (2-tailed) } & .000 \\
\hline \multicolumn{2}{|c|}{ a. Test distribution is Normal. } & \\
\hline
\end{tabular}

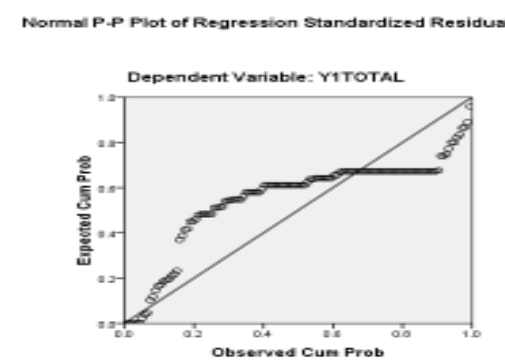

Gambar 1. P-P Plot dari Residual

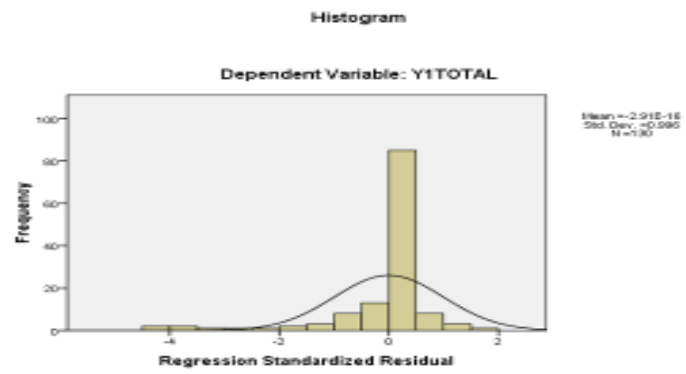

Gambar 2. Diagram Histogram dari Residual

Berdasarkan hasil analisis regresi di atas, dapat ditentukan model regresi yang terjadi antara Variabel Dependent $Y 1$ (Evaluasi) dengan Variabel Independent Implementasi " $X_{1}$ ", sebagai berikut : $Y=31.781+2.429 X_{1}$

Dari model ini dapat ditarik beberapa konklusi antara lain :

1. Variabel Implementasi (independent) memiliki kontribusi yang positif terhadap variabel dependent, ini terlihat dari tanda variabel independet

2. Dilihat dari koefisen determinasi sebesar 38,2 $\%$, adanya potensi $61,8 \%$ variabel independent lain yang mempengaruhi variabel dependent, berdasarkan hal tersebut, perlu adanya penelitian lanjut yang dapat mengkaji permasalahan tersebut.

3. Hasil pengujian kenormalan residual, masih menghasilkan pelanggaran asumsi, sehingga perlu adanya pendekatan analisis statistik lain yang tidak memerlukan pengujian kenormalan residual.

\section{Regresi Linier Sederhana antara variabel bebas $\mathrm{X}$ (Implementasi) dengan Variabel Terikat Y2 (Efektivitas)}

Koefisien determinasi pada regresi linear sering diartikan sebagai seberapa besar kemampuan semua variabel bebas dalam menjelaskan varians dari variabel terikatnya. Berdasarkan hasil pada Tabel 5. diperoleh nilai koefisien determinasinya hanya $19,5 \%$. Hal ini memberikan interpretasi kemampuan variabel bebas (Unsur-unsur pada Implementasi) dalam menjelaskan varians dari variabel terikatnya (unsur-unsur evaluasi) adalah hanya sebesar $19,5 \%$. Berarti terdapat $80,5 \%$ varians variabel terikat yang dijelaskan oleh faktor lain yang belum masuk dalam penelitian ini 
Tabel 5. Output Nilai Koefisien Determinasi Variabel X1 dan Y2

\begin{tabular}{|c|c|c|c|c|c|c|c|c|c|}
\hline \multirow{2}{*}{ Model } & \multirow{2}{*}{$\mathrm{R}$} & \multirow{2}{*}{ R Square } & \multirow{2}{*}{$\begin{array}{l}\text { Adjusted R } \\
\text { Square }\end{array}$} & \multirow{2}{*}{$\begin{array}{l}\text { Std. Error } \\
\text { of the } \\
\text { Estimate }\end{array}$} & \multicolumn{5}{|c|}{ Change Statistics } \\
\hline & & & & & $\begin{array}{c}\text { R Square } \\
\text { Change }\end{array}$ & F Change & df1 & df 2 & $\begin{array}{c}\text { Sig. F } \\
\text { Chang } \\
\mathrm{e}\end{array}$ \\
\hline 1 & $.448^{\mathrm{a}}$ & .201 & .195 & 5.43852 & .201 & 32.152 & 1 & 128 & .000 \\
\hline \multicolumn{10}{|c|}{$\begin{array}{l}\text { a. Predictors: } \\
\text { X1TOTAL }\end{array}$} \\
\hline
\end{tabular}

Tabel 6., merupakan output yang digunakan untuk pengujian model secara simultan atau bersama-sama. Uji yang dilakukan disebut simultan test (F-test) yang bertujuan untuk melihat apakah secara bersama-sama variabel bebas berpengaruh terhadap variabel terikat atau tidak. Prosedur pengujiannya adalah $H_{0}$ : tidak

ada variebel bebas yang berpengaruh terhadap variabel terikat. Dengan tingkat signifikansi $\alpha=0,05$, diperoleh hasil pengujian bahwa Sig F (0.0000) $<\alpha$, maka $H_{0}$ ditolak. Dapat disimpulkan dengan tingkat kepercayaan 95\% variabel bebas berpengaruh secara signifikan terhadap variabel terikat.

Tabel 6. Analisis Variansi (ANOVA) X1 dan Y2

\begin{tabular}{|l|l|l|l|l|c|c|}
\hline \multicolumn{2}{|c|}{ Model } & Sum of Squares & df & Mean Square & F & Sig. \\
\hline 1 & Regression & 950.973 & 1 & 950.973 & 32.152 & $.000^{\mathrm{a}}$ \\
\cline { 2 - 7 } & Residual & 3785.919 & 128 & 29.577 & & \\
& Total & 4736.892 & 129 & & & \\
\hline \multicolumn{2}{|l|}{ a.Predictors: . (Constant), X1TOTAL } & & & \\
\hline \multicolumn{2}{|l|}{ b.Dependent Variable: Y2TOTAL } & & &
\end{tabular}

Tabel 7., selanjutnya merupakan tabel pengujian signikansi dari masing-masing variabel bebas terhadap variabel terikat. Dengan tingkat signifikansi $\alpha=0,05$, diperoleh hasil pengujian bahwa Sig $t$ untuk intersep dan masing-masing variabel berturut-turut 0,002 dan
0,000. Kedua nilai signifikansi tersebut masih lebih kecil dari nilai $\alpha$, maka $H_{0}$ ditolak. Dapat disimpulkan dengan tingkat kepercayaan 95\%, nilai intersep, dan koefisien dari masing-masing variabel bebas berpengaruh secara signifikan terhadap variabel terikat.

Tabel 7. Nilai Koefisien dari Parameter Regresi X1 terhadap Y2

\begin{tabular}{|c|c|c|c|c|c|c|}
\hline \multirow{2}{*}{\multicolumn{2}{|c|}{ Model }} & \multicolumn{2}{|c|}{ Unstandardized Coefficients } & \multirow{2}{*}{\begin{tabular}{|l} 
Standardized Coefficients \\
Beta
\end{tabular}} & & \multirow{2}{*}{ Sig. } \\
\hline & & B & Std. Error & & & \\
\hline & (Constant) & 23.339 & 4.534 & & 5.147 & .000 \\
\hline & X1TOTAL & .687 & .121 & .448 & 5.670 & .000 \\
\hline
\end{tabular}


Dengan melihat tampilan grafik histogram maupun grafik normal plot pada gambar 3 dan 4 , dapat disimpulkan bahwa grafik histogram memberikan pola distribusi normal. Sedangkan pada grafik normal plot terlihat titik-titik menyebar disekitar garis diagonal. Berdasarkan kedua gambar tersebut di simpulkan data residual berdistribusi normal. Namun demikian untuk lebih memastikan hasil pengujian kenormalan residual, kita gunakan pengujian kolmogorov smirnov. Dalam prosedur pengujian kenormalan kolmogorov smirnov, di hipotesiskan bahwa $H_{0}$ : data mengikuti distribusi normal, dengan kriteria pengujian Tolak $H_{0}$ bila nilai signifikansi $<\alpha$. Berdasarkan hasil tabel diatas, nilai signifikansi (0.006) < dari $\alpha=0,05$ hal ini Ho diterima yang artinya data residual tidak mengikuti distribusi normal.

Tabel 8. Uji Kolmogorov-Smirnov Untuk Kenormalan Residual Regresi X1 dan Y2

\begin{tabular}{|l|l|l|}
\hline \multicolumn{2}{|l|}{} & \multicolumn{2}{|l|}{ Unstandardized Residual } \\
\hline $\mathrm{N}$ & Mean & 130 \\
Normal & .0000000 \\
Parameters & Std. Deviation & 5.41739911 \\
\hline Most Extreme & Absolute & .150 \\
Differences & Positive & .117 \\
& Negative & -.150 \\
\hline Kolmogorov-Smirnov Z & 1.711 \\
\hline Asymp. Sig. (2-tailed) & .006 \\
\hline \multicolumn{2}{|c|}{ a. Test distribution is } \\
\multicolumn{2}{|c|}{ Normal. } & \\
\hline
\end{tabular}

Normal P-P Plot of Regression Standardized Residual

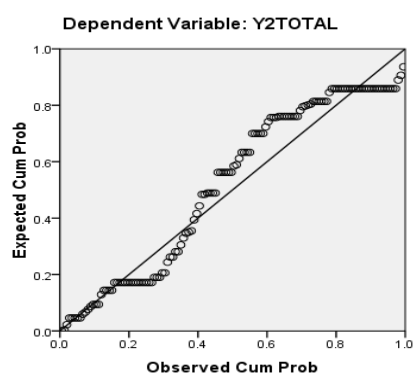

Gambar 3. Gambar P-P Plot dari Residual

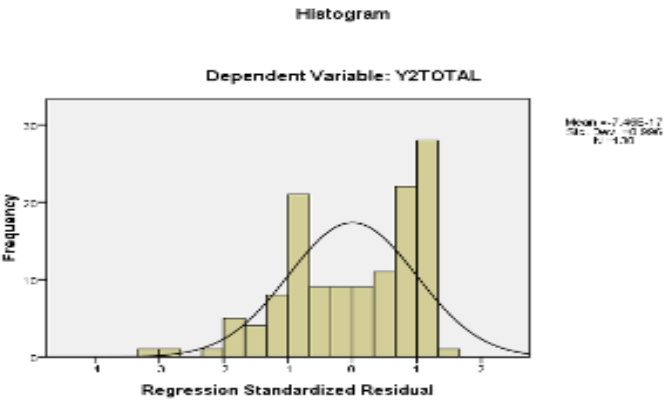

Gambar 4. Diagram Histogram dari Residual

Berdasarkan hasil analisis regresi di atas, dapat ditentukan model regresi yang terjadi antara Variabel Dependent $\square$ 2(Efektivitas) dengan Variabel Independent Implementasi “ $\square$,", sebagai berikut :

$$
\square=23.334+0.687 \square_{1}
$$

Dari model ini dapat ditarik beberapa konklusi antara lain :

1. Variabel Implementasi (independent) memiliki kontribusi yang positif terhadap variabel dependent, ini terlihat dari tanda variabel independet

2. Dilihat dari koefisen determinasi hanya sebesar $19,5 \%$, adanya potensi yang saangat besar $80,5 \%$ variabel independent lain yang mempengaruhi variabel dependent, berdasarkan hal tersebut, perlu adanya penelitian lanjut yang dapat mengkaji permasalahan tersebut.

3. Hasil pengujian kenormalan residual, masih menghasilkan pelanggaran asumsi, sehingga perlu adanya pendekatan analisis statistik lain yang tidak memerlukan pengujian kenormalan residual.

\section{SIMPULAN}

Dari paparan di bagian temuan dan pembahasan penelitian ini, diperoleh beberapa kesimpulan penting dalam penelitian ini. Berdasarkan hasil olahan data yang telah terkumpul terlihat perbedaan bahwa implementasi program AKPPM di UPBJJ-UT Padang lebih baik dibandingkan UPBJJ-UT Bengkulu. Jumlah mahasiswa program AKPMM lebih banyak UPBJJ-UT Bengkulu, jumlah pendaftar di UPBJJ-UT Padang lebih seragam 
sehingga dapat langsung semester 4 , sedangkan di UPBJJ-UT Bengkulu jumlah pendaftar lebih sedikit dan masa mengajar serta pengalaman mengajar berbeda-beda sehingga banyak yg memuli dari semester 1. Program AKPMM di UPBJJ-UT Padang memiliki dampak yang lebih positif dibandingkan di UPBJJ-UT Bengkulu. Hal ini terlihat dari pengetahuan, keterampilan, dan sikap peserta. Berdasarkan uji statistik diketahui bahwa terdapat pengaruh yang signifikan antara variabel implementasi terhadap variabel evaluasi dan efektivitas program AKPMM di Universitas Terbuka. Artinya, implementasi secara signifikan mempengaruhi evaluasi dan efektivitas program AKPMM.

\section{DAFTAR PUSTAKA}

BKN. 2004. Aplikasi Evaluasi Jabatan Terhadap Keadilan Internal Gaji Pegawai Negeri Sipil. Jakarta: Badan Kepegawaian Negara.

Cascio, Wayne F. 1995. Managing Human Resources:Productivity, Quality Of Work, Life, Profits. New York: Mc.GrawHill.

Gaspersz, Vincent. 1998. Manajemen Produktivitas Total: Strategi Peningkatan Produktivitas Bisnis Global. Jakarta: Gramedia.

Gibson, James L., John M. Ivancevich dan James H. Donnely Jr., 1994, Organisasi: Perilaku, Struktur, Proses. (Terjemahan) Edisi Delapan. Jakarta: Binarupa Aksara

Hamalik, Oemar.2009. Dasar-dasar Pengembangan Kurikulum. Bandung: PT. Remaja Rosdakarya.

Keban, Yeremias T. 2008. Enam Dimensi Strategis Administrasi Publik: Konsep, Teori, dan Isu. Yogyakarta: Gava Media.
Subarsono, AG. 2010. Analisis Kebijakan Publik: Konsep, Teori dan Aplikasi. Yogyakarta: Pustaka Pelajar.

Sudirman. 1991. Ilmu Pendidikan. Bandung: Remaja Rosdakarya.

Syah, Muhibbin. 2002. Psikologi Pendidikan. Bandung: Remaja Rosdakarya.

Sevilla, Consuelo G. Tuwu. Syah, Alimudin. Alam.2006. Pengantar Metode Penelitian. Jakarta (ID): UI Press.

Sugiyono, (2008), Metode Penelitian Kuantitatif, Kualitatif dan $R \& D$, Alfabeta, Bandung.

Tilaar, H.A.R dan Riant Nugroho. 2012. Kebijakan Pendidikan: Pengantar Untuk Memahami Kebijakan Pendidikan dan Kebijakan Pendidikan Sebagai Kebijakan Publik. Yogyakarta: Pustaka Pelajar.

Tracey, William T. (ed). 1994. Human Resources Management and Development Handbook. New York: Arnacom.

Tayibnapis, F Y. 2000. Evaluasi Program. Jakarta: Rineka Cipta.

UU Pokok kesehatan No. 9 Tahun 1969

Van den Ban, A.W. dan H.S. Hawkins. 1999. Penyuluhan Pertanian. Yogyakarta: Penerbit Kanisius.

Wahab, Solichin Abdul. 2004. Analisis Kebijaksanaan: Dari Formulasi ke Implementasi Kebijaksanaan Negara. Jakarta: Sinar Grafika.

Wibawa, Samodra, Yuyun Purbokusumo dan Agus Pramusinto. 1994. Evaluasi Kebijakan Publik. Jakarta: Raja Grafindo Persada.

Winarno, Budi. 2002. Teori dan Proses Kebijkan Publik.Yogyakarta: Media Pressindo. 